\title{
Practising Religion across National Borders: A Study of Ghanaian Christian Churches in Amsterdam
}

\author{
Justice Richard Kwabena Owusu Kyei / Mary Boatemaa Setrana / \\ Rafal Smoczynski
}

The paper investigates the rationale behind the multiplicity of cross-border relations of Ghanaian Christian churches in Amsterdam and the involvement of Ghanaian second generations in transnational religious discourse. It contributes to filling the empirical research gap in the transnational religious practices of Sub-Saharan African Christian churches in the diaspora. This study also contributes to the empirical literature on the intergenerational transnational religious activities of Sub-Saharan Africans in Europe. The study raises three main research questions: to what extent do Ghanaian churches in Amsterdam engage in transnational religious practices? In what ways do second generation Ghanaians engage in the transnational religious field? Is mission reverse or internal among Ghanaian Christian churches in Amsterdam? The paper adopts ethnographic research methodology of in-depth interviews with fifty second generation Ghanaians and nine Ghanaian Christian churches in Amsterdam, participant observation and informal interviews which occurred in Amsterdam from January 2014 until January 2015. The research concludes that inasmuch as some Ghanaian churches in Amsterdam and some second generation Ghanaians engage in activities that strengthen their integration into mainstream Dutch society, they are also involved in transnational religious activities. The nation state poses structural constraints in the transnational religious field but some Ghanaian churches exercise agency to contest or re-define some of the restrictions. The study recommends that further research investigates gender relations in the transnational religious social field of the studied Ghanaian Christian churches in Amsterdam.

Justice Richard Kwabena Owusu Kyei is a Ph.D. candidate in the Graduate School for Social Research, Institute of Philosophy and Sociology of the Polish Academy of Sciences, Warsaw, Poland. His research interests are: immigrant integration, sociology of religion, transnational migration, political sociology, citizenship and gender.

Mary Boatemaa Setrana is a lecturer at the Centre for Migration Studies, University of Ghana, Accra. Her Ph.D. in Migration Studies was a sandwich programme between the Radboud University, Nijmegen, the Netherlands and the University of Ghana. Her research interest includes transnational migration and diaspora, gender and migration, sexuality and citizenship. 
Rafal Smoczynski is an assistant professor at the Institute of Philosophy and Sociology of the Polish Academy of Sciences, his research interest revolves around social control studies, classic and late modern social theory, and political philosophy.

\section{Introduction}

"Transnational religious practices represent one type of transnational activity that migrants engage in but until now has not been sufficiently explored" (Levitt 2001, p. 8). The paper investigates the rationale behind the multiplicity of cross-border relations of Ghanaian Christian churches in Amsterdam and the involvement of second generation Ghanaians in the transnational religious discourse. Scholars of transnationalism have recognized that some Ghanaian emigrants have double commitments because they integrate into the life of their resident countries and simultaneously influence the lives of families, friends and communities in Ghana (Mazzucato 2005). Much of their economic activities have been acknowledged through individual remittances and Home Town Associations (HTA) (Ahinful 1999; Mazzucato / Kabki / Smith 2006; Nijenhuis / Zoomer / Meerts 2012). This paper contributes to the burgeoning empirical literature (see Tonah 2007; Dijk $2002,2004)$ on the transnational religious practices of Ghanaian immigrants in Europe with the case of Ghanaians in Amsterdam.

The traditional migration literature holds that immigrants are supposed to assimilate into the host society and abandon their original cultural heritage or maintain their ethnic identities with the view of returning to their country of origin sooner or later which sometimes becomes a myth of return (Alba / Nee 1997; Martiniello 2005). As a result, most of the research on immigrant religions in the Netherlands has mainly focused on the receiving countries (Ter Haar 1998; Tubergen 2005, 2007; Vernooij 2004). Since Glick-Schiller, Basch and Blanc-Szanton (1992) introduced the concept of transnationalism into ethnic and migration studies there have been various discussions on the transnational practices of immigrants. It is well established in the literature that immigrants and their children engage in various forms of transnational activities (Levitt 2001, 2009; Pessar / Mahler 2003; Portes / Guarnizio / Landolt 1999; Smith 2006). Even though transnationalism is not a new phenomenon, it is unique among contemporary immigrants due to the broader phenomenon of globalisation and the advancement of communication technologies like the internet and the easy access to international travel that have compressed the distance between time and space (Giddens 1990; Hasalova 2010; Mazzucato et al 2006; Mügge 2010; Portes 2001; Portes et al, 1999; Smith 1998; Vertovec 2004). This paper contributes to the emerging scholarship on the transnational religious practices of Sub-Saharan African migrants in Europe (e.g. Adogame 2000, 2008; Asamoah-Gyadu 2008, 2010; Ter Haar 2008) by investigating the simultaneity of immigrant integration 
and the sustained transnational ties of some Ghanaian Christian churches in Amsterdam.

Some scholars of immigrant integration (Jones-Correa, 1998; Suarez-Orosco 1998) doubt the persistence of transnationalism among immigrants. Some (Portes et al 1999) also maintain that the phenomenon is not widespread among immigrants, as only a small proportion of first generation immigrants are involved. These scholars argue that there is less likelihood that immigrants' transnational practices extend beyond first generation immigrants as transnational parents may not generate transnational children (Alba / Nee 2003; Kasinitz / Mollenkopf / Waters 2004). However, some transnational migration scholars have noted that second generations actively engage in different forms of transnational practices (Pessar / Mahler 2003; Smith 2006). Espiritu and Tran (2002) argue that some second generation Vietnamese in the United States of America (US) search for spouses within the transnational social field. Some other studies in the US have also concluded that second generations circulate between home and host countries so that they can learn the culture and language of their home country (Menjivar 2002; Parrenas 2001). Mügge (2010) noted in her study of transnational politics of the main immigrants groups in the Netherlands that second generations are involved in the varied forms of transnational political practices. Arthur (2010) noted in his work on female second generation Africans in the US that some of them construct identities that are transnational in nature to contest the marginalised connotations attached to blackness. This study seeks to contribute to the empirical literature on the intergenerational transnational religious activities of Sub-Saharan Africans in Europe using the case of Ghanaians in Amsterdam.

The study of Ghanaian immigrants in Amsterdam is interesting because of their recent arrival but the rapid growth in the number of Ghanaians and their churches in the Dutch society. The study raises three main research questions: to what extent do Ghanaian Christian churches in Amsterdam engage in transnational religious practices? In what ways do second generation Ghanaians engage in the transnational religious field? Is mission reverse or internal among Ghanaian Christian churches in Amsterdam? The paper is organized as follows: it begins by defining the problem and it proceeds with the definition of some relevant concepts. This is followed by the description of Ghanaian immigration and the origin of Ghanaian churches in Amsterdam. Consequently, the study presents the data and method which are followed respectively by discussion, conclusion and recommendations.

\section{Definition of Relevant Concepts}

Transnationalism is defined here as the process whereby immigrants and nonmigrants "develop and maintain multiple religious relations [...] that span borders" (Basch / Glick-Schiller / Blanc-Szanton 1994, p. 7). Immigrants is defined 
here as those Ghanaians who have emigrated and reside in the host country while non-migrants are those Ghanaians who reside in Ghana but may or may not occasionally travel outside the country and stay for less than three months. Immigrants do not only respond to different states simultaneously, but they also respond to social institutions such as religious groups that exist within the nation state and across borders. Immigrant and non-migrant actors engage in multidimensional activities within the transnational religious social field.

Bourdieu $(1969,1985)$, one of the advocates of the concept of social field, argues that the social field is a human construction of the interaction between people and among groups of people with their own set of beliefs and distinctive logic of practice, which are, however, not fixed but flexible. Bourdieu explains that there are different forms of social field within a social setting and the rules of the game govern the power relations among the social agents. Glick-Schiller and her colleagues (see: Levitt / Glick-Schiller 2004; Glick-Schiller 2005; Glick-Schiller / Fouron 1999) have extended the concept of social field into transnational studies. According to Levitt and Glick-Schiller (2004) immigrants and immigrant organisations within the transnational social fields engage in daily activities and relationships which are influenced by multiple sets of laws and institutions. The focus of this paper is on the transnational religious social field. Transnational religious social field is defined here as "a set of multiple interlocking networks of social relationships through which ideas, practices, and resources are [...], exchanged, organised and transformed" (Levitt / Glick-Schiller 2004, p. 1009).

Immigrant integration is defined broadly in this study as the interaction between the host country and its immigrants (Favell 2001). It is an interactive process between migrants and the receiving society. The study operationalises integration of immigrant organisations in the host society as the acquisition of fixed or immobile property, length of stay, communication in the language of the receiving country, country of origin of congregation and number of branches established. The individual indicators of integration are operationalised as period of stay in the host society, naturalisation and proficiency in the Dutch language.

African Initiated Church (AIC) is defined here as those churches formed by a person or group of persons of African descent or which has its origin in Africa. The acronym AIC is sometimes described as African Indigenous Church to indicate that those churches originated from persons of African origin or it began in Africa. African Initiated Churches can be grouped into two. On the one hand, there are those churches that have their headquarters in Ghana and exist in the Netherlands as branches. On the other hand some Ghanaian immigrants establish new churches in the Netherlands and they try to extend their branches back home or to other nation-states in the Diaspora (Adogame 2008).

The term second generation is used in migration studies as an umbrella term to classify different categories of immigrant children (Aparicio 2001) and there are no consensus in the literature as to who qualifies to be called second generation (Aparicio 2007; Favaro / Napoli 2004; Timmerman / Vanderwaeren / Crul 2003). 
This research conceptualises second generation as any child born in the Netherlands or who entered the Netherlands at/before the age of six (6) with at least one parent as Ghanaian and is now eighteen (18) years and above as of the time of the data collection (see Crul 2005, p. 5; Martens / Veenman 1996).

Reverse mission as a concept is contested in literature as some scholars define it in terms of the mere presence of African style of Christianity in Europe which is somehow neglected by European Christians (Gerloff 2001; Wijsen 2007). Other scholars define it as the intention and actions of African Christians to integrate into mainstream European society (Adogame 2000; Ter Haar 1998, 2001). This research blends these two points of view as they are perceived as complementary. Reversed mission is defined here as the presence of African style of Christian worship in Europe and the intentions as well as actions of African Christian Churches in establishing their presence in mainstream European societies.

\section{Ghanaian Immigration and Origin of Ghanaian Churches in Amsterdam}

Mass immigration of Ghanaians in the Netherlands is a relatively new phenomenon compared to the Turkish, Moroccans, Antilleans and Surinamese who entered massively from the late 1960s onwards (Statistics Netherlands 2015). However, the number of Ghanaians has grown steadily in the last three decades (Statistics Netherlands 2015). According to the Amsterdam Bureau for Research and Statistics, Ghanaian immigrants in the Netherlands were about 12,480 in 1996 but as of 2014, the number has increased to 22,556 (Statistics Netherlands 2015). The total number of second generation Ghanaians in the Netherlands has more than doubled. In 1996, there were 3,056 second generation Ghanaians in the Netherlands but in 2014, it had gone up to 8,871 (Statistics Netherlands 2015). More than half of Ghanaian immigrants live in Amsterdam and they are the fifth largest immigrant group in Amsterdam after the Moroccans, Turkish, Antilleans and Surinamese (Gemeente Amsterdam 2013a, p. 62).

Most Ghanaian immigrants settled in the Bijlmer district of Amsterdam and to a lesser extent in The Hague (Dietz / Mazzucato / Kabki / Smith 2011). Ghanaians in Amsterdam became well known in the Netherlands after a plane crash into some buildings in Amsterdam southeast in September 1992, which claimed many Ghanaian lives while others were injured (Knipscheer / de Jong / Kleber / Lamptey 2000). Ghanaians in the Netherlands are from different ethnic groups in Ghana but most of them are Akans; the Akans consist of Asantes, Akuapim and the Fante. Ghanaians are visible in the Netherlands through their churches, shops (food, clothing), media (television and radio broadcasting) and magazines. In spite of the medium education level of Ghanaians in the Netherlands, they are employed in semi-skilled and unskilled jobs mainly due to low proficiency in the 
Dutch language, discrimination in the labour market (Cheonni 2002) and the cumbersome process of foreign diploma recognition by the Dutch government.

The period of mass emigration of Ghanaians in the 1980s coincided with the peak period of new religious movements, especially Pentecostal/Charismatic churches in Ghana. The Pentecostal and Charismatic churches sprang up at a time when Ghanaian socioeconomic and political life was unstable and faced difficult challenges and these new churches promised hope, prosperity and salvation which was appealing to the masses (Asamoah-Gyadu 2010; Baffoe 2013; Gifford 2004). Pentecostal/ Charismatic churches in Ghana instilled in their members the need to leave the shores of their homeland to the "Promised Land" (especially Western Europe and the United States of America), where success awaited them. The Pentecostal/ Charismatic churches in Ghana established the prosperity-migration nexus. Ghanaians who left the shores of the country to seek greener pastures took along the religious zeal.

In the Netherlands a growing number of African-led churches were initiated mostly by Ghanaians in the 1990s. According to Ter Haar (1995, p. 6), as of 1995 there were about seventeen Ghanaian Christian churches in Amsterdam, and forty African led churches in 1997 in Amsterdam alone. The number of Ghanaian churches in Amsterdam has grown to about 150 as of 2013 (Bos 2013). There are two main types of churches among Ghanaians in the Netherlands and Mensah (2009) also noted this in his study of Ghanaian Christian churches in Canada. The first group consists of the Traditional missionary churches like the Catholic, Methodist, Presbyterian and the Seventh Day Adventist (SDA) churches. The second category consists of those churches that are Pentecostal/Charismatic in nature which were mostly initiated by Ghanaians rather than foreign missionaries.

\section{Data and Method}

The study adopted ethnographic research methodology of in depth interviews, participant observation (Flick 2009; Suryani 2013), both electronic and hard copies of church documents and government statistical data. The fieldwork took place in Amsterdam from January 2014 until January 2015. Other sources of data were from records of church meetings, the constitution of the churches, church annual programmes, church websites, videos, the website of the Dutch statistical office, books, online scholarly journals and search engines like Google Scholar and jstor.org database.

The study adopted a purposive sampling technique which is a type of nonprobability sampling that permits the selection of the units to be observed on the basis of the judgement of which units will be the most useful or representative (Babbie 2007, p. 184). Two types of purposive samples, namely second generation Ghanaians who attend Ghanaian Christian churches in Amsterdam and Ghanaian Christian churches in Amsterdam were selected in this thesis. The snowball 
sampling technique was used to recruit sixty (60) second generation Ghanaians within Ghanaian Christian churches in Amsterdam to participate in life history interviews but after fifty (50) interviews, new themes were not coming out as the process had reached saturation. As a result, fifty (50) second generation Ghanaians participated in the research out of which thirty-five (35) were females and fifteen (15) were males. Semi-structured in depth interviews were also conducted with nine (9) Ghanaian Christian churches in Amsterdam and they were also recruited through a purposive sampling technique based on the dominant churches attended by the second generation Ghanaians who were interviewed.

The interviews were audio recorded and transcribed verbatim. Line by line the data were manually categorised into analytic units under descriptive words or category names. The information was organised into themes and subthemes (Rossman / Rallis 1998, p. 171). The themes and sub-themes were analysed for each participant and they were also connected to other interviewees with quotations. Descriptive and inferential analyses of data were employed in this work (Guba / Lincoln 1982; Hammersley 1992). These interpretations were based on state of the art and personal interpretations. The voluntary nature of the research participation and the possibility of withdrawing as a participant at any moment were clearly specified in the informed consent (Kyei / Smoczynskyi 2016; Daly / McDonald 1996). This work adopted a qualitative research method and so the research findings and conclusions are setting centred, which cannot be generalised statistically, but this is compensated through rich and thick description of the fieldwork. The themes and sub-themes developed from the data however, allowed generalisation of some of the results based on the logic of generalisation by categorisation.

\section{Churches "Here" and "There": Transnational formation of Ghanaian Churches}

For the purpose of this study "here" is defined as the country of residence of immigrants and "there" as the country of origin of immigrants. Three typologies are built into the discussion on the formation of Ghanaian Christian churches in Amsterdam. The first category comprises of Ghanaian Pentecostal/Charismatic churches that were already established in Ghana. The second category is mainline Ghanaian Protestant churches with their headquarters in Ghana. Lastly, Ghanaian Pentecostal/Charismatic churches that were formed in Amsterdam as new churches.

The Church of Pentecost recounts the transnational religious formation of the branch of the church in Amsterdam:

In August 1990, a group of six (6) people [...] began a house fellowship with the objective of gathering all the Church Of Pentecost members, scattered all over the city of Am- 
sterdam, [...] They sent a message to the church headquarters in Accra of the establishment of the church here in Holland. [...]. The then Chairman and the International Mission Director of the church, [...] visited the church for the first time in 1992, where officers of the existing Presbytery were ordained into various positions. The leadership unrelenting in their zeal for lost souls extended their propagatory mission to the city of The Hague [...]. They then continued to Rotterdam to open another branch there. The leadership continued to Liege and Brussels in Belgium (Church of Pentecost, n. a.: para 2, $3,4,6)$.

A founding member of the Resurrection Power and Living Bread Ministries International also recounted the transnational formation and activities of the church. He recounted that:

The church began in Ghana in the early 1980s and then in the late 1980s some of the Ghanaian immigrants here in Amsterdam gathered together to form a branch of the church. The church grew rapidly and in 1990, a leading founding member of the church in Ghana was invited to inaugurate the church here in Amsterdam. The church has spread to several cities in the Netherlands, like The Hague and Rotterdam. Amsterdam is the headquarters of all the branches in Europe. The pastors of the church in Europe and America have timely meetings here in Amsterdam and sometimes the bishop who is the head of the whole church visits us (interview on 07-08-2014).

The findings showed that the establishment of some Ghanaian Christian churches in Amsterdam are intertwined with transnationalism. The mass emigration of Ghanaians into Europe and other Western countries provided the opportunity for some Ghanaian Christian churches to establish and strengthen their universal missionary work of evangelisation which is depicted in their designated names like "international", "world" (Ter Haar 1998; Dijk 1997). Some Ghanaian immigrants who were already members of these churches before travelling abroad carried with them the zeal to continue in the African Pentecostal form of worship which was quasi absent in the Dutch society. The research showed that the religious zeal may have resulted from the reminiscence of some immigrants in religious life back home. Immigrants' religion happens to be one of the few resources that they carry along to the host nation (Hirschman 2004). It may also be a result of the language barrier that prevented most of the newly arrived Ghanaian immigrants to be part of Dutch churches.

In spite of the presence of mainline Protestant churches in Europe, some Ghanaian immigrants in Amsterdam decided to plant Presbyterian and Methodist churches of Ghana to reflect their way of worship back home. Tonah (2007) and Mensah (2009) also noted a similar pattern among Ghanaians in Germany and Canada respectively in their works. A founding member of the Presbyterian church of Ghana in Amsterdam recounted that: 
In the year 2000 about seven of us who already attended Dutch Protestant churches decided to bring together Ghanaians to form Presbyterian Church of Ghana. [...]. The following Sunday about one hundred Ghanaian immigrants in Amsterdam gathered to worship as Presbyterians and many of these people were members of the Presbyterian church of Ghana before migrating. The church developed very fast and we informed the headquarters in Ghana about our plans and progress in establishing a Presbyterian church of Ghana here in the Netherlands. A Ghanaian Presbyterian priest who was already in the Netherlands was temporarily assigned to us by the church hierarchy in Ghana. In October 2003 the Moderator of the Presbyterian church of Ghana came to inaugurate our branch as Netherlands District of the Presbyterian church of Ghana (interview on 25-09-2014).

A founding member of the Holland Mission Circuit of the Methodist church of Ghana narrated the beginnings of the church. He noted that:

In the year 1997 about 20 Ghanaians in Amsterdam were motivated by the growing number of Ghanaians in the city to form Methodist church of Ghana in order to promote its missionary vision and aims. In the same year we sent a letter to the headquarters of the Methodist church of Ghana to inform it of our intention and level of engagement. In 1998, I was sent to The Hague to establish a new branch over there. In the year 1999 the presiding bishop of the Methodist church of Ghana came to visit us and together with him we went to register the Methodist church of Ghana in the Netherlands. As at that time we already had two societies in the Netherlands located in Amsterdam and The Hague. The Amsterdam congregation alone had about 180 members in 1999. The presiding bishop was encouraged by our motivation and enthusiasm so he raised our status in the church to Mission Circuit which is not normally given to only two church branches in the Methodist church (interview on 06-11-2014).

The study showed that even though some of the church planters of the studied mainline Protestant churches attended Dutch Protestant churches, there was still a religious gap in the way of worship as they felt nostalgic for what they left "there". Moreover, the inability to have the necessary social space within the Dutch Protestant churches to climb the hierarchical ladder and to engage in missionary work might have called for the establishment of some mainline Ghanaian Protestant churches in Amsterdam. From the data, Ghanaian immigrants who are members of the Seventh Day Adventist church worshipped on Saturdays together with Dutch co-religionists, but the Ghanaian members worked strenuously to have their own branch under the Dutch Seventh Day Adventist Conference. From the data, interaction between local Dutch churches and Ghanaian Christian communities sometimes creates intercultural tension, which results in the creation of independent immigrant churches or branches. The longing for the religious practice did not call for return home; rather it necessitated experiencing similar religious practice "here". The establishment of the branches of the churches "here" was made possible due to simultaneous cross-border re- 
lations within the transnational religious social field with the mother churches "there".

Communication technologies facilitated the reaching of a large proportion of the Ghanaian population in Amsterdam, as well as interaction with the headquarters over "there". Advancement in communication technologies has made religious transnationalism unique in recent times because of the compression of the distance between time and space (Giddens 1990; Portes 2001; Setrana / Kyei 2015; Smith 1998; Vertovec 2004). From the findings, the transplanted Christian churches both mainline Protestant and Pentecostal/ Charismatic churches were made possible due to the consistent interaction, the seeking of information and guidelines from "there". The negotiations in the transnational religious field permitted the formation of some of the studied Ghanaian Christian churches that reflect the institutional and cultural practices of the mother churches back home.

Apart from planting the branches of some already established Christian churches among Ghanaian immigrants, some Ghanaian immigrants in Amsterdam formed new and independent Christian churches. Redemption Faith International church and Pentecost Revival church International began in the Netherlands with no roots back home or abroad but have managed to extend their branches beyond the borders of the host nation. The head pastor of Redemption Faith International church recounted that:

From the early 1990s when the Ghanaian population was growing we decided to form a church which resembled our way of worship in Ghana but we did not want to link it with any pre-existing church. Most of us belonged to several churches when we were in Ghana and we were not ready to begin the establishment of any of those churches but to have an interdenominational church. We therefore had to arrive at a name which was neutral but significant to our Christian values and at the end of the day we chose the name Redemption Faith International [...]. We have tried establishing branches in other parts of Europe, like Belgium or the United Kingdom, but due to time constraints and inability to find suitable persons to handle those branches they have not been successful. But in 2010 we successfully established a branch in Ghana. At the registry department in Ghana the signatories are the same persons who signed during the establishment of the Amsterdam branch plus the resident pastor in Ghana. Amsterdam is our headquarters and wherever we establish a new branch two or three of us from here will be part of the signatories (interview on 07-09-2014).

In the first instance the myth of return to the home country led to the formation of a religious group that reflected the ones back home. The myth of return faded away and paved way for the formation and sustainment of a new church with a new name in Amsterdam.

The head pastor of Pentecost Revival Church International also recounted that: "In the year 2000 Pentecost Revival Church International started here in Amsterdam and it has remained a vibrant church. We have sister churches in 
different parts of Belgium and also in Ghana. In each of the countries we have a national coordinator and I am the general overseer with my office here in Amsterdam" (interview on 15-08-2014).

Unlike the European missionaries most of whom were already ordained ministers or were assigned from their home countries to embark on missionary activity, the data from this research showed that all the planters of the studied Ghanaian Christian churches did not immigrate to the Netherlands primarily for pastoral activity. Rather they arrived in the Netherlands as asylum seekers or labour migrants, or through family reunification, but with a bottom-up approach, they established Ghanaian Christian churches. Out of the nine Ghanaian Christian churches in Amsterdam interviewed, only three of the head pastors were sent from home as ordained ministers for missionary work. The three pastors arrived after the studied Christian churches had already been established. The other six pastors were ordained subsequently, after some years in the Netherlands where they attended pastoral colleges or were ordained after some years of pastoral experience in their churches in Amsterdam.

The planting of the studied Pentecostal/ Charismatic churches started earlier in Amsterdam compared to the mainline Protestant churches in this study. In the beginning of their missionary activity, the mainline Protestant churches appealed first to those Ghanaian immigrants who were members back home. This recruitment process facilitated the establishment of the mainline Ghanaian Protestant branches in Amsterdam. Some of the people however, were already absorbed into other Ghanaian Pentecostal/ Charismatic churches in Amsterdam. In a Dutch religious pluralistic marketplace, each church competes for members and various forms of strategies are adapted to attract and maintain members (Chiswick 2013). The data from the fieldwork showed that most Ghanaian Christian churches in Amsterdam compete among themselves for consumers in the religious marketplace (Iannaccone 1998) which sometimes results in divisive competition (Hanciles 2014, p. 133).

The transnational religious social field is not given, rather it has to be created, nurtured and maintained and it requires a lot of resources. In order to examine the stability of the transnational religious activities, there is the need to find out whether the activity is institutionalized or not (Mügge 2010, p. 36). Activities are institutionalized when they are predictable, constant and structured (Beerling 1978 cited in Penninx 1988). Activities are described as institutional when they take place on regular and organised basis (Mügge 2010). The church planters of some of the studied Ghanaian Christian churches sought to institutionalise and formalise the newly formed branches with their mother churches "there" by communicating their presence in the host country. The church planters sought recognition from their respective headquarters in Ghana to strengthen their ecumenical and pastoral ties (Mensah 2009). A person or persons of authority in the headquarters of the churches "there" travelled "here" to inaugurate the external branches of the churches and gave them the appropriate names according 
to the prescription of the churches. Data from the fieldwork revealed that names like "circuit", "district", "council", "national" or "conference" were assigned accordingly to the branches of the Ghanaian Christian churches in Amsterdam depending on their size and pastoral engagement. From the data, the moderator of the Presbyterian church of Ghana, like all the other churches with headquarters in Ghana, extends their authority beyond the nation-state due to the planting of branches of their churches in the diaspora. The inauguration of the external branches by the hierarchy of the churches from "there" institutionalises the transnational religious social field (Basch et al 1994; Levitt 2009). This enables the regular and constant interaction of the headquarters of the churches "there" with their branches "here". The hierarchy of the churches exercise their authorities simultaneously "here" and "there". Some of the newly established Ghanaian Pentecostal/Charismatic churches in Amsterdam like Pentecost Revival church International manage to transact in the transnational religious field as they establish branches of their churches back home as well as in other parts of Amsterdam and even in Belgium.

The research also showed that not all the studied Ghanaian Christian churches are able to nurture, sustain and institutionalise transnational religious activities. The head pastor of Love Christian Centre recounted that:

About 17 years ago Christian International Ministries, which was headquartered in London, extended its branch to the Netherlands but after some time the branch in Amsterdam became autonomous and now bears the name Love Christian Centre. Before Love Christian Centre became autonomous, we used to do programmes together with the other churches in Europe [...]. As a church we have tried to establish branches in Ghana but we have not been successful because of limited resources (interview on 22-10-2014).

Some of the one man churches (referring to individually owned and recently established Pentecostal/ Charismatic churches) find it much more difficult to establish branches of their churches outside Amsterdam. From the data, attempts by some of the one man churches to establish branches outside Amsterdam are curtailed by multiple factors among which are financial and time constraints. Although Redemption Faith International Church could not maintain branches of the church established in Belgium and the United Kingdom, it was able to engage in the transnational religious field with the planting of a branch of the church in Ghana. 


\section{Transnational Recruitment of Pastors and the Role of the Nation-state}

After the planting and inauguration "here" of some of the studied Ghanaian Christian churches in Amsterdam by the hierarchy from "there", the branches request pastors from the headquarters in Ghana. The data showed that the executive council for each church in Ghana then appoints a reverend minister for pastoral work in the host country for a period of time after which the pastors return back home and another pastor is sent from home or from any part of the diaspora to replace him or her. With the exception of the studied Ghanaian Christian churches in Amsterdam that were established as new and independent churches in the Netherlands, all the other churches in this study recruited their pastors from Ghana or from the Diaspora at least in the initial stages of their presence in Amsterdam.

The transnational process of recruiting pastors is not without challenges. Transnational actors are classified into three: individual (migrants, non-migrants), collective (immigrant churches) and the nation-state (Mügge 2010). The host nation poses loads of bureaucratic challenges in issuing immigrant visas for the recruited pastors in the transnational religious social field and some are not able to begin their pastoral duties at the stipulated time. One of the pastors in the analysed churches recounted that:

When I was assigned to the Netherlands, the embassy delayed in issuing the working permit for religious motive because of the European Law which states that the employer has to prove that the manpower is in short supply within the European Union before somebody from outside could be employed. There was urgent need for my pastoral work in the church here in Amsterdam so I requested for a tourist visa and in a second instance I went back home for the working permit for religious motive. The embassy granted me the visa mainly because of my proficiency in different Ghanaian languages as well as some foreign languages (interview on 07-11-2014).

Fortress Europe with its persistent restrictive immigration laws and securitization (Basso / Perocco 2003; Morokvasic 2013) sometimes deters the entrance of some missionary workers in some of the studied Ghanaian Christian churches in Amsterdam. The nation-state continues to be a significant actor in the transnational religious practices of some of the studied Ghanaian Christian churches. Transnationalism has not "deterritorialised" (Appadurai 1991; Basch et al 1994) the nation-state, rather transnationalism continues to take place within the boundaries of the nation-state (Faist / Kivisto 2008). The laws of the nation-state enhance or restrain the transnational recruitment of pastors for some of the studied Ghanaian Christian churches.

Some of the studied Ghanaian Christian churches in Amsterdam exercise agency and try to circumvent some of the obstacles posed by the nation-state by 
allowing the appointed pastors to apply for other forms of visas to hasten their entry into the Netherlands. Agency is defined here as "the capacity for social actors to reflect on their position, devise strategies and take action to achieve their desires" (Bakewell 2010, p. 1694). A founding member in one of the analysed churches recounted that:

When the church was inaugurated by the headquarters in Ghana, we requested for a pastor from Ghana. Due to the cumbersome Dutch immigration laws it was almost impossible to employ a priest from Ghana. The church was advised to enrol the pastor in a school so that he could apply for a student visa, which was easier to acquire compared to the working visa for religious motive. We enrolled him in a school and he is with us as our district pastor (interview on 16-09-2014).

The nation-state as an actor in the transnational practice exerts its influence by regulating the level of engagement within the transnational social field. Through agency some of the studied Ghanaian Christian churches in Amsterdam contest the structural constraints posed by the state which are perceived as discriminatory and a hindrance to engagement in the transnational religious field. Instead of applying for the needed visa that may be rejected or delayed, another form of visa is applied so that the recruited pastors can readily begin their pastoral work. Tension is sometimes created in the transnational religious social field among the different social actors which are negotiated and compromised.

Another founding member of one of the Ghanaian churches in Amsterdam in this analysis also related that:

We sent a letter to the headquarters in Ghana for a pastor to take care of the church when we established the church but it was a cumbersome and long process. When the presiding bishop came to witness our level of progress he realised that we really needed a priest, so in 2000 he sent us a Ghanaian pastor who was already within the European Union (EU) to take care of the church here in Amsterdam. In our church the maximum number of years to stay in a particular place is five, but those of us here in the Netherlands have some difficulties with the issuance of visa for our pastors so we are exempt from this law. It took us more than one year before the pastor was granted a residence permit. In the initial stages he had to plead with his former employer in the previous EU country to extend his stay in that country so that he could stay here legally. The visa system is difficult so we have kept the same priest till now (interview on 16-11-2014).

Transnationalism from below practised by most of the studied Ghanaian Christian churches encounter nation-state structural impediments in their engagement in cross-border relations. Some Ghanaian churches in Amsterdam are however, informed of the immigration rules that govern Fortress Europe and take advantage of the Schengen rules that allow free movement of persons within Schengen member states. The Schengen treaty (European Communities 2001), however, restricts access to the labour market by non-European Union nationals. 
Through collective agency, some of the studied Ghanaian Christian churches circumvent the structural constraints posed by the Dutch government as they engage pastors who are already within Fortress Europe. Some of the recruited pastors stay and work in the host country sometimes without the requisite residence permit required by the host nation. The collective agency helps to maintain and strengthen the relations within the transnational religious social field. The collective agency is made possible because the studied Ghanaian Christian churches require baptismal certificate, not passport or residence permit for representation (Jongeneel 2003).

Due to the difficulties in obtaining a working permit for some recruited pastors, some of the studied Ghanaian Christian churches in Amsterdam encourage their members, especially second generations, to show interest in the priestly ministry so that they could be formed as pastors. The data showed that the Amsterdam SDA Ghana church recently ordained the first second generation Ghanaian among its congregants who had gone through the requisite religious formation needed to be a pastor in the church (Field Notes 2014). A founding member of the Methodist church of Ghana in Amsterdam noted that:

If anyone wants to be a pastor in the Methodist church of Ghana, the person has to attend Trinity College in Ghana, after which he or she could be ordained as a priest in the church. At the moment we have one of second generation migrant who is training to be a priest. We want to build the church in a way that we would not have to recruit pastors from Ghana so that the problem of acquiring visas could be avoided (interview on 06-112014).

A founding member of the Presbyterian church of Ghana in Amsterdam also narrated that:

The Holland-Belgium district has been able to recruit people from our branches as pastors. They went home for the seminary formation and some of them have completed their studies and are now doing their internship. One has already been ordained as a pastor. It is a positive indication for the future of the church as we would not have to recruit pastors from home and that will hasten the work of evangelisation here.

Through conscious efforts, some Ghanaian churches in Amsterdam exhort the second generations in their congregation to priestly formation. This is to ensure intergenerational transfer of the missionary activity began in the host country by first generation migrants to second generations (interview on 25-09-2014).

Some of the studied Ghanaian Christian churches in Amsterdam have their seminaries back home, so their priestly candidates are sent "there". There is constant flow of interaction, exchange of human capital between "here" and "there" that aims at enriching the transnational religious social field. The transnational religious social field is not limited to "here" and "there" as some of the studied Ghanaian Christian churches build their own formation centres in some 
European countries. The priestly candidates do not have to travel back home; rather, they could have the formation outside the host and home countries. The head pastor of the Amsterdam branch of the church of Pentecost recounted that:

To become a pastor in the church of Pentecost, the person has to be nominated by the local church and vetted by a board which comprises of representatives from Ghana and the national executives in the Netherlands. The selected individuals used to be sent to the Pentecost University in Ghana but now a new training school has been opened in Birmingham, United Kingdom, so interested persons in the priestly ministry in Europe go there for their formation [...]. We used to recruit pastors and apostles from Ghana but since the church in Europe has trained enough pastors and due to bureaucratic difficulties in obtaining working permit for pastoral purposes, the church transfers pastors within the European Union. We have an apostle in charge of international missions who takes care of all the transfers and he is based in the headquarters in Ghana (interview on 23-10 2014).

Through agency, some Ghanaian churches in Amsterdam have embarked on strategies that lessen the burden of recruitment of pastors from "there". They are reacting to the structural problems posed by the Dutch government in the carrying out of their missionary works in the Netherlands. Transnationalism re-defines and challenges the institutionalised structures of the nation-state. Moreover, within the transnational religious social field, the individual and collective social actors both at home and abroad are in constant interaction to ensure that the religious market place (Iannaccone 1998) in the host country is structured and developed.

\section{Ghanaian Churches in Amsterdam as Development Partners}

In this section the paper discusses the flow of resources within the transnational religious social field and the unequal relations that surround the flow of money. It examines if the financial remittance influences development back home. In the literature on transnationalism of Ghanaian immigrants, it has been established that immigrants remit financially to their families and relatives back home at the individual level (Ahinful 1998; Mohan 2006). Collectively, Home Town Associations and other ethnic organisations (Mazzucato / Kabki / Smith 2004; Nijenhuis / Zoomer / Meerts 2012) also remit financially to the development of their towns. Data from the fieldwork showed that some of the studied Ghanaian churches financially remit to their headquarters in Ghana or to their branches back home without a reciprocal financial remittance from home. One of the head pastors in this analysis recounted that:

The pastor and the congregation in the church work on a voluntary basis because the income of the church is such that once we pay our basic bills and the mortgage for the 
building, very little is left for the church. We do not give any allowance to the pastors for the pastoral work they do, but if someone is sick and the church has to go and visit we buy fuel. However, the church here in Amsterdam has employed the services of a pastor in Ghana to take care of the branch over there and we send money every month to him as his salary. In addition we are financing the building of a church edifice in Ghana (interview on 07-09-2014).

A founding member of one of the churches in this analysis also noted that:

As a Mission Circuit of the church we have a financial quota that we contribute to the headquarters of the church in Ghana. Apart from the obliged contribution, we also financially support the running of the church's university in Ghana. The church in Amsterdam has adopted some of the local churches in Ghana and we remit financially to them regularly (interview on 16-11-2014).

Another founding member of one of the churches in this analysis recounted that:

All the districts of the church are obliged to pay some stipulated amount of money into the coffers of the main church in Ghana which we also do as a district. We send money to needy local branches in Ghana to supplement their pastoral work. The church sends money home to meet some of the financial needs of the church's university. The church also has hospitals in Ghana and we support them with money and equipment (interview on 16-09-2014).

A Ghanaian second generation Ghanaian in this analysis recounted that:

Every quarter of the year the church celebrates the Mission Day and on that day the church appeals to the congregation for financial and material contributions to be sent to the branches of the church in needy places. On the Mission Day, a video documentary is shown in church after which an appeal for funds is made to contribute to the success of the missionary work of the church [...]. The church also collects donations for various developmental projects like schools and hospitals in Ghana and on regular basis a video is shown in church about the progress of the project (interview on 20-04-2014).

The United Nations Development Fund (UNDP) defines development as the possibility of creating "an enabling environment for people to enjoy long, healthy and creative lives" (1990, p. 9). The financial remittances from some of the studied Ghanaian churches in Amsterdam are not only for religious activities but some are also geared towards the socioeconomic development of their home country. Some of the Ghanaian churches in Amsterdam contribute to development back home as they seek to find solutions to the human needs of the citizenry in the home country. Through investment in educational institutions back home, some of the studied Ghanaian Christian churches in Amsterdam contribute to the human capital growth of the Ghanaian economy. 
In line with the transnational literature (Mazzucato et al 2006; Smart / Smart 2003; Smith 2006) this study also lauds the analysed Ghanaian churches for their financial and material remittances. This study however revealed a contradictory finding that within the transnational religious social field there is inequality in the transfer of financial remittances, as the burden of remitting financially falls only on the analysed Ghanaian churches in Amsterdam. Findings from the research revealed that some of the members of the analysed churches are compelled to sacrifice from their low incomes to remit back home, whereas non-migrants do not contribute financially to the establishment of the analysed Ghanaian churches in Amsterdam or in their pastoral activities.

On average, Ghanaian immigrants in Amsterdam have low income levels due to discrimination on the labour market, low proficiency in the Dutch language (Cheonni 2002) and difficulty in diploma conversion. According to the 2012 Amsterdam Poverty Monitor, more than forty percent of Ghanaian children in Amsterdam live in poor households (Gemeente Amsterdam 2013b, p. 28). Congregants of the analysed Ghanaian churches are, however, compelled to contribute financially to the missionary work of their local churches as well as the pastoral and developmental needs of their churches in the home country.

A male second generation Ghanaian lamented about the consistent demand for money in his church. He narrated that:

When I get to church always there is a preaching about money, oh God give them money to pay their tithe, always like give money, money and all that the church does is to preach and pray to God for money, to support the work of God. The church has a lot of developmental projects both at home and abroad and it needs to enrich its finances in order to carry out these activities (interview on 09-10-2014).

\section{Another female second generation respondent also bemoaned that:}

The paying of the tithe at the end of the month is very painful. As a student I receive very little money from my part-time job but I am encouraged to pay one tenth as tithe in church. Sometimes my contribution is not up to one tenth of the salary but I am doing my best. I do believe in the Christian doctrine of offering that is why I continue to give notwithstanding the difficulties. The money is also needed to support the church here in Amsterdam and at home for its pastoral and developmental projects (interview on 0408-2014).

Some studies on individual financial remittances of immigrants (Nzama/ Maharaj 2014) concluded that second generations do not have strong connections with their home countries as such they have no obligations to remit. Data from this research however showed that at the organisational level, some of the studied second generation Ghanaians are obliged to contribute towards the financial remittance of their churches back home. Gifford (1988) argued that congregants 
are encouraged to give generously through tithes and offerings to God for it is an act of faith which will eventually gain them earthly and heavenly riches. WährischOblau also noted in her work among West African led Pentecostal congregations in Germany that the preaching is centred on the giving of tithes and offerings to the Lord so that the Lord in turn will bless them with riches $(2009$, p. 2). The research showed that the financial resources of the studied Ghanaian Christian churches are generated from the meagre income of the congregants as they are motivated by their religious and theological faith.

\section{Transnational Conflict and Conflict Resolution}

[...] - contentment resulting to misunderstanding and disunity among the Presbytery adversely affected the entire church nationwide. In 1995, the crises escalated to an extent that it called for the intervention of the entire International Executive Members from Ghana. The International Executive Members made strenuous efforts to resolve it but it prevailed until 1998, and even divided the large Amsterdam Central Assembly into two rival Assemblies 1 \& 2. In 1998, the International Executive Members transferred Rev. A L. Angoh to Holland to help resolve the crises once and for all. With intensive prayers, good counselling, deep revelation and able leadership of the International Executive Members, God through him finally brought the restoration of the yearning peace, love and unity which eluded the church (Church of Pentecost, n. a. para. 8).

The above recount reveals that the transnational religious social field is not void of conflicts. Christian theological literature has established the presence of conflict and conflict resolution in Christendom (see: Stott 2002; Susek 1999; Yperen 2002). Conflict is defined here as the attempt made by a person or some persons within a religious group to oppose, resist or coerce the will of others. The conflicts are complex and multifaceted, which some of the studied Ghanaian Christian churches try to resolve from varied angles within the transnational religious social field. When there is conflict, the headquarters back home sometimes intervene to settle the situation in spite of the distance. The uniqueness of transnationalism among contemporary immigrants lies in the near-instantaneous nature of communication across national borders and long distances (Portes 1996). The conflict within some Ghanaian Christian churches in Amsterdam is multi-stranded and is lived daily across national borders. The consequences of the conflict do not affect only Ghanaian immigrants in Amsterdam but also non-migrants within the transnational religious social field. A founding member of one of the participating churches in Amsterdam reiterated that:

After some few years, the church in Amsterdam went through some administrative problems which led to the split of the church into two. Internally we tried to resolve the problem but it was not successful. The pastor in charge of international affairs at the church's headquarters in Ghana was informed and he travelled to the Netherlands to 
bring us together again but he was not successful. Other national executives from home tried to reach some compromise and bring the two groups together again but the agreements did not last long. It was not until we had a resident pastor from Ghana who managed to strike a deal with both sides to bring peace and harmony (interview on 16-092014).

Yperen (2002) argued that conflicts in churches are normal but it is the approach adopted by the leadership in resolving it that makes it escalate or die out. Not all church conflicts are resolved; unfortunately some lead to schism and breakaway. A head pastor in one of the analysed churches narrated that:

I started the Heaven church here in Amsterdam and I helped to open branches in Belgium, Austria and Australia. At a point in time church politics set in from home and abroad. Amsterdam is Akan (an ethnic group in Ghana) dominated and some were complaining that they did not want me, a Ga (an ethnic group in Ghana) to be their head. I happened to be the first $\mathrm{Ga}$ in the elite of the church as the others were Akan as of that time. The tension in the Amsterdam branch of the church heightened. Representatives from the headquarters in Ghana came to Holland to settle the dispute on several occasions but the waters did not settle down [...]. I was later sent to Belgium to continue my ministry over there. After some years in Belgium, the headquarters of the church in Ghana wanted to transfer me to Austria which I refused for family reasons. The leadership of the church in Ghana therefore suspended me from exercising my pastoral work in the church. The relationship with the church worsened and that led to my excommunication from the church (interview on 15-09-2014).

Another founding member of one of the studied Ghanaian Christian churches recounted that:

The church grew very rapidly here in Amsterdam and this created some challenges for the initiators and leaders of the church as they were not trained pastors. There were complaints of mismanagement of church funds and lack of transparency in the activities of the church. The bishop who is the head of the church drew the attention of the pastors here in Amsterdam to the problem at hand. The persistence of the problem in the church in Amsterdam prompted the bishop to transfer the head pastor from Amsterdam to Germany but the pastor refused to adhere to the transfer. After several attempts to convince the head pastor to take the new appointment failed, the head pastor decided to break away from the church and form his own church before any punishment was meted out to him (interview on 20-10-2014).

Data from the fieldwork showed that ethnic differences within the transnational religious social field could generate conflict. Ethnic differences within immigrants from the same country are mostly overlooked in migration studies as if they are a block of people with no unique differences. The research showed that when ethnic differences create tension and conflict, the headquarters back home on several 
occasions intervene to resolve the ethnic conflict in the church that could impede the missionary work of some of the analysed churches in the host nation.

Sometimes conflict arises between the leadership of the church in the host nation and the hierarchy at home. Due to the imbalance in the exercise of authority, the verdict or the consequence tilts against the leadership of the churches in the host nation. Ghanaian immigrants in Amsterdam, through agency, plant branches of already existing churches in the host nation. After the inauguration of the church, however, the headquarters exercise authority and control over the running of the church from "there" and intervenes whenever necessary. The shared experiences from the ethnographic findings showed that power is unequally distributed in the transnational religious social field of some of the studied Ghanaian Christian churches.

\section{The Dynamics of Sustaining Immigrant Christian Churches}

Integration of immigrant organisations into the mainstream host country is a gradual process and some of the Ghanaian Christian churches in this study have taken steps to attract autochthones and other immigrant groups to join their congregation. The data from the fieldwork showed that some Ghanaian Christian churches in Amsterdam are convinced that the establishment of youth Sunday church services and the use of English and Dutch languages can appeal to more non-Ghanaians. There is therefore a shift from the use of only Ghanaian languages in some of the studied Ghanaian Christian churches to the simultaneous use of both English and the Dutch languages with the aim of attracting "outsiders". A founding member of one of the participating churches recounted that:

The Amsterdam branch of the Circuit has established the youth service which uses English and Dutch languages during the church service. This was established to retain our children in the church to continue the work of evangelisation. It also aims at alleviating the language barrier so that non-Ghanaians could be motivated to join the Sunday church service (interview on 06-11-2014).

A founding member of the Presbyterian church of Ghana in Amsterdam recounted that:

The future of the church is bright because some of the youth are actively involved in its activities. The youth are fluent in the Dutch and English languages plus the Akan language which puts them at an advantageous position in relating with public institutions (interview on 25-09-2014).

A female second generation Ghanaian recounted the formation of a new Sunday youth service in her church. She recounted that: 
The leaders of the church realised that some of the youth did not understand the Akan language well, so they decided to help us establish our own Sunday service. During the last two years, in collaboration with the church executives, the youth started their own Sunday youth service. The service is in English with Dutch translation and all the segments are done by us, the youth, except the homily. The number has grown from five to about thirty-five. We feel comfortable inviting our friends from school to Sunday church service (interview on 19-09-2014).

Another female respondent also recounted that:

Fifteen years ago the Youth Sunday service was established in the church and the number has grown from forty-five to about two hundred. Although most of the congregants are Ghanaians, there are quite a sizeable number of the congregation who are non-Ghanaians. The church hopes to recruit more non-Ghanaians but it takes time (interview on 10-06-2014).

According to Myer and Lee (1996) the acquisition of immobile property in the host country is a vital indicator of immigrant integration. The data showed that some of the analysed Ghanaian Christian churches have bought their places of worship and some are in the process of acquiring them. Moreover, some of the Ghanaian Christian churches in this analysis have purchased the places of residence of their pastors. Ownership of church building and other immobile properties (Sinning 2006) by some of the studied Ghanaian Christian churches in Amsterdam may enhance the long term process of their integration into the Dutch society. The head pastor of one of the participating churches recounted that:

We have already bought and paid for one of our church buildings in Amsterdam. Next week we will open a new church in The Hague and next month we will open another one in Rotterdam. We invest our money in the buying of church buildings because they provide us with stable living conditions in the Netherlands. We secure these places so that our children will build upon our good works as they are better informed of the Dutch society (interview on 23-10-2014).

Another head pastor in a participating church also recounted that:

We have completed the process of purchasing some land to put up a church building here in Amsterdam. We want to secure a physical space within the Dutch society in order to strengthen our physical presence (interview on 07-01-2015).

In spite of the transnational religious practices of some of the studied Ghanaian Christian churches in Amsterdam, some also seek to simultaneously integrate into the Dutch society. From the data, some of the studied Ghanaian Christian churches acquire fixed properties in the Dutch society as a way of visibly making 
their presence felt in the Dutch society. The acquisition of immobile properties also provides some form of security in their continuous existence in the Dutch society.

\section{Reverse Mission or Internal Mission?}

Findings from the research showed that the missionary agency of some Ghanaian immigrants was fundamental in the formation and planting of the studied Ghanaian Christian churches in Amsterdam. In order to establish Ghanaian churches, evangelisation strategies were adopted to attract new members to the congregation. Communication technologies were used to readily reach a large proportion of the Ghanaian population in Amsterdam. A founding member of the Presbyterian church of Ghana in Amsterdam recounted that:

We announced on Ghanaian radio and television stations in Amsterdam that all those who decided not to attend any church till the arrival of the Presbyterian church of Ghana, the time is due because we have started one. To those who have joined Pentecostal/ Charismatic churches waiting for the establishment of Presbyterian Church of Ghana, you can now return for we have begun one [...]. The Amsterdam branch of the church has been able to embark on missionary activities in other parts of Holland and Belgium. Recently the Presbyterian Church of Ghana in Holland went to Liege, Belgium to evangelise. Through the works of evangelisation we have been able to open new branches in several parts of Holland and Belgium. The Netherlands District has expanded and now it is officially known as the Netherlands-Belgium District of the Presbyterian church of Ghana (interview on 25-09-2014).

A founding member of the Holland Mission Circuit of the Methodist church of Ghana related a similar strategy adopted by his church in mobilising new members at the initial stages of their existence in Amsterdam. He recounted that:

The founding members went to the Ghanaian radio and television stations in Amsterdam and appealed to the Ghanaians who are Methodists to return to their roots for we have begun a branch of the Methodist church of Ghana here in Amsterdam (interview on 0611-2014).

The use of the radio and television in recruiting new members is common among all the studied Ghanaian Christian churches in Amsterdam. The data showed that some of the congregation in the analysed Ghanaian Christian churches in Amsterdam consequently engaged in outreach programmes to evangelise. They evangelise among Ghanaian immigrants in different cities in the Netherlands and sometimes extended the work of evangelisation to some cities in Belgium. From the data, the first stage in the formation of new branches or new churches among the studied Ghanaian Christian churches in Amsterdam could be described as 
internal mission. The head pastor of one of the analysed Ghanaian Christian churches narrated the missionary strategy adapted by his church in planting new branches in cities outside Amsterdam. He recounted that:

The church first establishes contact with one person or group of persons in a new city and through that contact, a few of the church executives go there to evangelise to other Ghanaians in that city. In the second instance, the church in Amsterdam organises a group visit and celebrate church service, after which the group embarks on home to home visitation of Ghanaians and other English speaking African immigrants living in that city. We do not have any intention of limiting our missionary work to Ghanaian immigrants but we want to first address the Ghanaian problem and then later extend our activity to non-Ghanaians (interview on 15-08-2014).

The study showed that most of the studied Ghanaian Christian churches began with the formation of prayer groups or fellowships in the homes of some members or in coffee shops. From the findings, some of the Ghanaian churches in this analysis embarked upon fervent prayer, open air crusade and house to house evangelisation to ensure the establishment and maintenance of their churches. The findings also emphasised the involvement of the mother churches "there" in the recruitment of members "here" for the newly formed branches in the diaspora. The mother churches of some of the studied Ghanaian Christian churches back home encouraged non-migrant congregants to inform their families and friends in the Netherlands about the presence of branches of their churches in Amsterdam (Field Notes 2014). Multiplicity of missionary strategies is adopted both "there" and "here" to ensure the cementation of the transnational religious social field. Moreover, the findings showed that through the missionary agency of some Ghanaian immigrants and their churches in Amsterdam, the transnational religious social field is extended beyond the "here"-"there" nexus as new branches are established in other countries within the European Union.

Data from this fieldwork showed that the conviction of witnessing Christ's message of salvation is the prime motive for the planting of most Ghanaian Christian churches in the Netherlands and their subsequent extension to other European countries. In his work on immigrant churches in the Netherlands, Jongeneel (2003, p. 31) also noted that "Christian migrants are more missionminded $[\ldots]$. They usually propagate church planting and experience church growth. In many ways, they prove to be more dynamic and expansive than the established congregations and churches in Europe". A founding member of the Holland Methodist Mission Circuit recounted the motivation for planting branches of the Methodist church of Ghana in the Netherlands and Belgium. He recounted that:

Jesus Christ has commanded us as his disciples to go and preach the Gospel to the ends of the world. The Netherlands used to be a Christian country but the state and the citizens 
have privatised Christian religion. As the European missionaries brought the Gospel message to our country (Ghana), it is our belief that through us the Lord will restore Christianity in the Netherlands and in Europe as a whole. We are also aware that our life on earth is temporal so we need to evangelise in order to win the favour of God in the life after death [...]. By the grace of God we have extended the missionary work to different cities in the Netherlands and Belgium. Currently the Holland Mission Circuit comprises of the Holland section and the Belgium section. [...]. We are vigorously working to build new branches in Almere and Utrecht (interview on 06-11-2014).

The head pastor of one of the analysed churches also recounted that:

My church is situated in different parts of Holland but we still have a lot of work to do because we are called to spread the Gospel of Christ in Europe in much the same way as the Europeans did in the $19^{\text {th }}$ century. We face a lot of challenges as African immigrants like xenophobia and discrimination because of our colour. This makes it difficult to penetrate the non-Ghanaians, but with prayers and God's providence we shall succeed (interview on 07-01-2015).

Another head pastor also recounted that:

The church of Pentecost has a congregation in The Hague that is mainly Dutch. The pastors are Dutch and non-Ghanaians and the members are mostly non-Ghanaians and there are initiatives taken by the church to establish its presence in mainstream Dutch society by recruiting non-Ghanaians into the congregation (interview on 07-09-2014).

In spite of the challenges that entangle settlement in the host country, some Ghanaian Christian churches in Amsterdam manage to carry out mission work voluntarily and form new branches in and outside of Amsterdam. "For many African Christians in the diaspora, the recession of Christianity among westerners is a call to evangelism and the re-establishment of kingdom values in the lands of nineteenth-century missionaries. Mission is in reverse" (Asamoah-Gyadu 2008, para. 8). Moreover, the recruitment of autochthones as pastors in some of the analysed Ghanaian Christian churches in Amsterdam is strategic as it can facilitate the recruitment of native Dutch citizens and other non-Ghanaians into their congregation. Although the first group of people targeted during the process of evangelisation of almost all the churches in this study are Ghanaian immigrants, the mission intention of most of the Ghanaian churches in Amsterdam is to recruit non-Ghanaians and create networks within mainstream Dutch society so as to make their presence visible.

The research showed that the witnessing of the Christian faith is not limited to Ghanaian first generation immigrants. There is intergenerational mobility in the missionary activities of some of the studied Ghanaian Christian churches in Amsterdam, as some of the second generation respondents are an integral part of 
the transnational religious social field. A second generation Ghanaian in this study narrated that:

For me Christianity is a way of life. I try to live my life in the likeness of Christ and in so doing I preach Christ with my life. Together with the youth group, I go out to public places, hospitals and rehabilitation homes to preach the Word of God. We sometimes travel to the cities of Brussels, Antwerp and Liege in Belgium to evangelise and try to plant new branches of the church (interview on 10-11-2014).

Another second generation respondent also recounted how she contributes through music in the church's goal of perpetuating the message of salvation into the Dutch society. She recounted that:

I am a member of the youth choir and we evangelise through singing. We have performed in several Dutch churches and in other branches of my church in Belgium and the United Kingdom. The Lord has manifested in these occasions. We have had native converts through our song ministration (interview on 26-09-2014).

A male second generation respondent narrated his experience in the transnational religious social field. He narrated that:

Almost every year, the youth groups in the branches of our church in the Netherlands and in some other countries in Europe meet for a week of camping. We do different recreational and religious activities to strengthen our spirituality. We also build friendship networks and they are all aimed at our physical and spiritual growth (interview on 08-102014).

The sustainability of the transnational religious practices of some of the studied Ghanaian Christian churches in Amsterdam is ensured by the participation and involvement of some second generation Ghanaians. Individuals think and act in ways that are expected of them and with time they internalise these norms as their own (Sherkat 1998; Sherkat / Wilson 1995). The research showed that religious socialisation (Sherkat 2003) from infancy has formed some of the studied second generation Ghanaians to perceive Christianity as a way of life. The data showed that some second generation Ghanaians in this study are involved in witnessing their Christian faith within the Dutch public space and some extend it to other European countries like Belgium and the United Kingdom.

\section{Conclusions and Recommendations}

This ethnographic research has examined the multidimensional transnational religious practices of Ghanaian immigrant churches in Amsterdam within the transnational religious social field. The study showed that the transnational reli- 
gious social field is fluid rather than static with several social actors engaged in multifaceted activities. Inasmuch as some Ghanaian Christian churches in Amsterdam engage in activities that strengthen their integration in mainstream Dutch society, like the acquisition of immobile properties, establishment of church branches in different cities and recruitment of non-Ghanaian pastors; they are also involved simultaneously in transnational religious practices. Transnational religious practices of some of the studied Ghanaian churches in Amsterdam are therefore not incompatible with their integration into the host country rather they are complementary.

Although the creation of a religious space for the (re)production of cultural identity prompted the formation of Ghanaian churches in Canada as concluded in the work of Mensah (2009, p. 30), this study found that the conviction of missionary work is the prime motive for the establishment of the studied Ghanaian Christian churches in Amsterdam. Although the membership of all the studied Ghanaian Christian churches are predominantly people of Ghanaian origin, the study found that the mission intention of most of the studied Ghanaian Christian churches is reverse. The studied Ghanaian Christian churches in Amsterdam are relatively young so their reverse missionary activities are still in the process of acclimatising to their new environment and have the intention of attracting nonGhanaians through multi-layered reverse mission strategies. At this stage of their development, there is a conscious process of internationalisation (WährischOblau 2009, p. 48). The proliferation of Ghanaian Christian churches in metropolitan Dutch and Belgium cities could stimulate established Christian churches in Europe to revive and renew their mission and evangelism.

The research also concludes that some Ghanaian Christians in Amsterdam construct multiple identities within the transnational social field. The construction of Christian identity through religious ideas and symbols (Levitt 2001) is pivotal among some Ghanaian immigrants in Amsterdam (Ter Haar 1998) within the transnational religious social field. The Christian identity provides some Ghanaian immigrants with social safety that mitigates the harsh immigration experience in the migratory trajectory. In spite of the secularized nature of the Dutch public sphere (Bernts / Dekker / De Hart 2007), some of the studied second generation Ghanaians manifest their Christian identity. There is intergenerational missionary activity in some of the studied Ghanaian Christian churches.

The study concludes that transnationalism from below of some of the studied Ghanaian Christian churches in Amsterdam face structural constraints, such as strict restrictions in the issuance of immigrant visas and residence permits for some recruited pastors by the Dutch government. Some of the studied Ghanaian Christian churches however, exercise agency to contest and re-define some of these restrictions like the recruitment of pastors from European Union countries and the encouragement of members to priesthood in order to ensure the strengthening of the transnational religious social field. The transnational religious social field is not a level playing ground for all the social actors and as such 
there is consistent interaction, negotiation and competition among the social actors which sometimes leads to actions that are not in conformity with the set rules of some of the social actors especially the host nation.

The study recommends that further research investigates gender relations in the transnational religious social field of the studied Ghanaian Christian churches in Amsterdam. Moreover, the study recommends that the strict rules implemented in the recruitment of pastors by the Dutch government should be moderated in order to ensure effective engagement in the transnational religious field by all the social actors. The inability of some churches to obtain the visa for religious purposes leads to the request for visas which do not allow the government to benefit from the tax revenues to be gained from the services offered by the pastors during their stay in the Netherlands. Moreover the practice may adversely influence the process of integration of Ghanaian Christian churches in Amsterdam.

\section{References}

Adogame, Afe: "Up, Up Jesus! Down, Down Satan! Religiosity in the former Soviet Bloc - the Embassy of the Blessed Kingdom of God for All Nations", in: Exchange (37) 2008, pp. 310-336.

Adogame, Afe: "The Quest for Space in the Global Spiritual Marketplace. African Religion in Europe", in: International Review of Mission (89/354) 2000, pp. 400-409.

Alba, Richard / Nee, Victor: Remaking the American mainstream. Assimilation and the contemporary immigration. Cambridge, USA 2003.

Alba, Richard / Nee, Victor: "Rethinking assimilation for a new era of immigration", in: International Migration Review (31/4) 1997, pp. 826-874.

Aparicio, Rosa: "La literatura sobre los hijos de los inmigrantes", in: Migraciones (9) 2001, pp. 171-82.

Aparicio, Rosa: "The integration of the second and 1.5 generations of Moroccan, Domincan and Peruvian origin in Madrid and Barcelona", in: Journal of Ethnic and Migration Studies (33/7) 2007, pp. 1169-1193.

Appadurai, Arjun: "Global ethnoscapes: notes and queries for a transnational anthropology", in: Fox, Richard (ed.): Recapturing Anthropology. Sante Fe, New Mexico 1991, pp. 191-210.

Arhinful, Daniel K.: We Think Of Them: how Ghanaian migrants in Amsterdam assist relatives at home. Amsterdam 1999.

Arthur, John A.: African Diaspora Identities: negotiating culture in transnational migration. United Kingdom 2010.

Asamoah-Gyadu, J. Kwabena: "Mediating spiritual power: African Christianity, transnationalism and the media", in: Adogame, Afe / Spickard, Jim (eds.): Religion crossing boundaries: transnational religious and social dynamics in Africa and the new African Diaspora. Leiden / Boston 2010, pp. 87-103. 
Baffoe Michael: "Spiritual well-being and fulfilment, or exploitation by a few smart ones? The proliferation of Christian Churches in West African immigrant communities in Canada", in: Mediterranean Journal of Social Sciences (4/1) 2013, pp. 305-316.

Bakewell, Oliver: "Some reflections on structure and agency in migration theory", in: Journal of Ethnic and Migration Studies (36/10) 2010, pp. 1689-1708.

Basch, Linda / Glick-Schiller, Nina / Blanc-Szanton, Cristina: Nations Unbound, Transnational Projects, Postcolonial Predicaments, and Deterritorialized NationStates. Langhorne, Pennsylvania 1994.

Basso, Pietro / Perocco, Fabio (eds.): Gli immigrati in Europa: diseguaglianze, razzismo lotte. Milano 2003.

Bernts, Ton / Dekker, Gerard / De Hart, Joep: God in Nederland 1996-2006. Kampen 2007.

Bourdieu, Pierre: "The market of symbolic goods", in: Poetics (14/1) 1985, pp. 13-44.

Bourdieu, Pierre: "Intellectual field and creative project", in: Social science information (8/2) 1969, pp. 89-119.

Daly, Jeanne / McDonald, Ian: "Introduction: ethics, responsibility and health research", in: Daley, Jeanne (ed.): Ethical intersections: health research, methods and researcher responsibility. Sydney 1996.

Dietz, Ton / Mazzucato, Valentina / Kabki, Mirjam / Smith, Lothar: "Ghanaians in Amsterdam, their 'Good Work Back Home' and the Importance of Reciprocity", in: Journal of Global Initiatives (6/1) 2011, pp. 132-143.

Dijk, Rijk van: "Negotiating marriage: Questions of morality and legitimacy in the Ghanaian pentecostal diaspora", in: Journal of Religion in Africa (34/4) 2004, pp. 438 467.

Faist, Thomas / Kivisto, Peter (eds.): Dual Citizenship in Global Perspective: From Unitary to Multiple Citizenship. Basingstoke 2008.

Favaro, Graziella / Napoli, Monica (eds.): Ragazze e ragazzi nella migrazione. Milano 2004.

Favell, Adrian: "Integration policy and integration research in Europe: a review and critique", in: Aleinikoff, T. Alexander / Klusmeyer, Douglas B. (eds.): Citizenship today: global perspectives and practices. Washington D.C. 2001, pp. 249-299.

Gerloff, Rosewith: "Religion, Culture and Resistance: The Significance of African Christian Communities in Europe", in: Exchange. Journal for Missiological and Ecumenical Research (30/3) 2001, pp. 276-289.

Giddens, Anthony: The consequences of modernity. Cambridge 1990.

Gifford, Paul: Ghana's New Christianity: Pentecostalism in a Globalizing African Economy. London 2004.

Gifford, Paul: The Religious Right in Southern Africa. Harare, Zimbabwe 1988.

Glick-Schiller, Nina: "Transnational social fields and imperialism bringing a theory of power to transnational studies", in: Anthropological Theory (5/4) 2005, pp. 439-461.

Glick-Schiller, Nina / Basch, Linda / Blanc-Szanton, Cristina: "Transnationalism: A new analytic framework for understanding migration", in: Annals of the New York Academy of Sciences (645/1) 1992, pp. 1-24.

Glick-Schiller, Nina / Fouron, Georges E.: "Terrains of blood and nation: Haitian transnational social fields", in: Ethnic and racial studies (22/2) 1999, pp. 340-366. 
Guarnizo, Luis E. / Portes, Alejandro / Haller, William: "Assimilation and transnationalism: Determinants of transnational political action among contemporary migrants", in: American Journal of Sociology (108/6) 2003, pp. 1211-1248.

Guba, Egon G. / Lincoln, Yvonna S.: "Epistemological and methodological bases of naturalistic inquiry", in: Educational Communication and Technology Journal (30/4) 1982, pp. 233-252.

Hammersley, Martyn: What's wrong with ethnography? Methodological explorations. London 1992.

Hanciles, Jehu J.: "The future of missiology as a discipline: a view from the non-Western world", in: Missiology: An International Review (42/2) 2014, pp. 121-138.

Hirschman, Charles: "The role of religion in the origin and adaptation of immigrant groups in the United States", in: International Migration Review (38/3) 2004, pp. 12061233.

Hulsbosch, F.N.M.: Ghana. Landendocumentatie nummer 5. Amsterdam 1982.

Iannaccone, Laurence R.: "Introduction to the Economics of Religion", in: Journal of Economic Literature (36) 1998, pp. 1465-1496.

Itzigsohn, Jose / Dore Cabral, Carlos / Hernandez Medina, Esther / Vazquez, Obed: "Mapping Dominican Transnationalism: Narrow and Broad Transnational Practices", in: Ethnic and Racial Studies (22/2) 1999, pp. 316-339.

Jones-Correa, Michael: Between two nations: The political predicament of Latinos in New York City. Ithaca, New York 1998.

Jongeneel, Jan A.: "The mission of migrant churches in Europe", in: Missiology: An International Review (31/1) 2003, pp. 29-33.

Kasinitz, Philip / Mollenkopf, John H. / Waters, Mary C.: "Worlds of the second generation", in: id. (eds.): Becoming New Yorkers: Ethnographies of the new second generation. New York 2004, pp. 1-19.

Knipscheer, Jeroen W. / De Jong, Eleonore E. / Kleber, Rolf J. / Lamptey, Ekow: "Ghanaian migrants in the Netherlands: General health, acculturative stress and utilization of mental health care", in: Journal of Community Psychology (28/4) 2000, pp. 459-476.

Koopmans, Ruud / Statham, Paul / Giugni, Marco / Passy, Florence: Contested citizenship: Immigration and cultural diversity in Europe (= Social Movements, Protest, and Contention 25). Minnesota 2005.

Levitt, Peggy: "Roots and routes: Understanding the lives of the second generation transnationally", in: Journal of Ethnic and Migration Studies (35/10) 2009, pp. 17071716.

Levitt, Peggy: "Transnational Migration: Taking Stock and Future Directions", in: Global Networks (1/3) 2001, pp. 195-216.

Martens, Edwin P. / Veenman, Justus: "Inhalen en ingehaald worden in de opleidingsrace", in: Veenman, Justus (ed.): Keren de kansen? De tweedegeneratie allochtonen in Nederland. Assen 1996, pp. 15-38.

Mazzucato, Valentina / Kabki, Mirjam / Smith, Lothar: "Transnational Migration and the Economy of Funerals: Changing Practices in Ghana", in: Development and Change (37/5) 2006, pp. 1047-1072.

Miller, Alan S. / Rodney Stark: "Gender and Religiousness: Can Socialization Explanations Be Saved?”, in: American Journal of Sociology (107) 2002, pp. 1399-1423. 
Mollenkopf, John / Hochschild, Jennifer: "Immigrant political incorporation: comparing success in the United States and Western Europe", in: Ethnic and Racial Studies (33/1) 2010, pp. 19-38.

Morales, Laura / Pilati, Katia: "The political transnationalism of Ecuadorians in Barcelona, Madrid and Milan: the role of individual resources, organizational engagement and the political context", in: Global Networks (14/1) 2014, pp. 80-102.

Morokvasic, Mirjana: "Transnational mobilities and gender in Europe", in: Journal of Ars \& Humanitas (7/2) 2013, pp. 45-59.

Myers, Dowell / Lee, Seong Woo: "Immigration cohorts and residential overcrowding in Southern California", in: Demography (33/1) 1996, pp. 51-65.

Nzama, Ntokozo / Maharaj, Brij: "Honouring the Dual Commitment: Remittance Strategies of Ghanaian Migrants in Amsterdam", in: Migracijske i etničke teme (30/2) 2014, pp. 193-213.

Penninx, Rinus: Wie betaalt, bepaalt? De ontwikkeling en programmering van onderzoek naar migranten, etnische minderheden en woonwagenbewoners 1955-1985. Amsterdam 1988.

Pessar, Patricia R. / Mahler, Sarah J.: "Transnational migration: Bringing gender in", in: International Migration Review (37) 2003, pp. 812-846.

Portes, Alejandro: "Globalization from Below: The Rise of Transnational Communities", in: Smith, William P. / Korczenwicz, Roberto P. (eds.): Latin America in the World Economy. Westport, Connecticut 1996, pp. 151-168.

Portes, Alejandro: "Introduction: the debates and significance of immigrant transnationalism", in: Global Networks (1/3) 2001, pp. 181-194.

Portes, Alejandro / Escobar, Cristina / Radford, Alexandria: "Immigrant transnational organizations and development: A comparative study", in: International Migration Review (41/1) 2007, pp. 242-281.

Portes, Alejandro / Guarnizo, Luis E. / Landolt, Patricia: “The study of transnationalism: pitfalls and promise of an emergent research field", in: Ethnic and Racial Studies (22/ 2) 1999, pp. 217-237, DOI: 10.1080/014198799329468.

Rossman, Gretchen / Rallis, Sharon F.: Learning in the field: An introduction to qualitative research. Thousand Oaks, California 1998.

Sherkat, Darren: "Counterculture or Continuity? Examining Competing Influences on Baby Boomers' Religious Orientations and Participation”, in: Social Forces (76) 1998, pp. 1087-1115.

Sherkat, Darren: "Religious socialisation: sources of influence and influences of agency", in: Dillon, Michele (ed.): Handbook of the Sociology of Religion. Cambridge 2003, pp. 151-163.

Sherkat, Darren E. / Wilson, John: "Preferences, Constraints, and Choices in Religious Markets: An Examination of Religious Switching and Apostasy", in: Social Forces (73) 1995, pp. 993-1026.

Smith, Robert: Mexican New York: Transnational Lives of New Immigrants. Berkeley 2006.

Smith, Robert: "Transnational localities: Community, technology and the politics of membership within the context of Mexico and U.S. Migration”, in: Smith, Micahel P. / Guarnizo, Luis E. (eds.): Transnationalism from Below. New Brunswick 1998, pp. 196240. 
Snel, Erik / Engbersen, Godfried / Leerkes, Arjen: "Transnational involvement and social integration", in: Global Networks (6/3) 2006, pp. 285-308.

Stott, John: Calling Christian Leader: Biblical Models of Church, Gospel and Ministry. Leicester, England 2002.

Suárez-Orozco, Marcelo M. (ed.): Crossings: Mexican Immigration in Interdisciplinary Perspectives. Cambridge, Massachusetts 1998.

Susek, Ron: Firestorm: Preventing and Overcoming Church Conflicts. Grand Rapids 1999.

Ter Haar, Gerrie: "Enchantment and identity: African Christians in Europe", in: Archives de sciences sociales des religions (143) 2008, pp. 31-48.

Ter Haar, Gerrie: Halfway to Paradise: African Christians in Europe. Cardiff 1998.

Ter Haar, Gerrie: "Strangers in the promised land, African Christians in Europe", in: Exchange (24/1) 1995, pp. 1-33.

Timmerman, Christiane / Vanderwaeren, Els / Crul, Maurice: "The second generation in Belgium”, in: International Migration Review (37/4) 2003, pp. 1065-1090.

Tubergen, Frank van: "Religious affiliation and participation among immigrants in a secular society: A study of immigrants in the Netherlands", in: Journal of Ethnic and Migration Studies (33/5) 2007, pp. 747-765.

Tubergen, Frank van: The integration of immigrants in cross-national perspective: Origin, destination, and community effects. Wageningen, The Netherlands 2005.

Turner, Harold W.: Religious Innovation in Africa. Boston 1979.

United Nations Development Programme (UNDP): Human development report 1990. New York / Oxford 1990.

Vertovec, Steven: "Migrant transnationalism and modes of transformation", in: International Migration Review (38/3) 2004, pp. 970-1001.

Währisch-Oblau, Claudia: The Missionary Self-Perception of Pentecostal / Charismatic Church Leaders from the Global South in Europe. Leiden / Boston 2009.

Wijsen, Frans J. S.: "Van sociale missie naar integrale missie", in: Crijns, Hub (ed.): Missie, migranten en evangelisatie. 's Hertogenbosch, The Netherlands 2007, pp. 9-15. Yperen, Jim van: Making Peace: A Guide to Overcoming Church Conflict. Chicago 2002.

\section{Internet sources}

Amsterdam Ghana SDA Church: Ordination of our Brother Oliver Yeboah as Pastor at the Netherlands Union, 2014, available at: http://amsterdamghanasda.org/index. php?pid=announcedetail\&id=11 [11.12.2015].

Asamoah-Gyadu, J. Kwabena: African-led Christianity in Europe: migration and diaspora evangelism. Lausanne World Pulse Archives, 2008, available at: http://www. lausanneworldpulse.com/themedarticles-php/973/07-2008 [01.07.2016].

Bos, Dick van den: "Kerken in de Bijlmer zijn parels in Amsterdam-Zuidoost", in: Reformatorish Dagblad, 27.06.2013, available at: http://www.refdag.nl/kerkplein/ kerknieuws/kerken_in_de_bijlmer_zijn_parels_in_amsterdam_zuidoost_1_749924 [26.09.2016]. 
Chiswick, Carmel: Competition vs. monopoly in the religious marketplace: Judaism in the United States and Israel (IZA Discussion Paper No. 7188), 2013, available at: http://ftp.iza.org/dp7188.pdf [22.09.2016].

Choenni, Chan: Ghanezen in Nederland, een profiel, Den Haag: Ministerie van Binnenlandse Zaken en Koninkrijksrelaties. Directie Coiirdinatie Integratiebeleid Minderheden 2002, available at: http://mighealth.net/nl/images/3/34/Ghan.pdf [22.09.2016].

Church of Pentecost: Historical background of the Church of Pentecost Holland, n. a., available at: http://www.copmissions.org/holland.htm [10.10.2015].

Crul, Maurice: The Second Generation in Europe, paper presented at the Conference Seconde generazioni in Italia. Scenari di un fenomeno in movimento in Milano, 20.05.2005, available at: http://tiesproject.eu/component/option,com_docman/task, doc_download/gid,52/Itemid,142/index.html.pdf [26.09.2016].

Dijk, Rijk van: "From Camp to Encompassment: Discourses of Transsubjectivity in the Ghanaian Pentecostal Diaspora”, in: Journal of Religion in Africa (27/2) 1997, pp. 135-159, available at: http://doi.org/10.2307/1581683 [26.09.2016].

Dijk, Rijk van: "Ghanaian churches in the Netherlands Religion mediating a tense relationship", in: Merchants, Missionaries \& Migrants: 300 years of Dutch-Ghanaian Relations. Amsterdam 2002, pp. 89-97.

Gemeente Amsterdam: Amsterdam in Cifers 2013. Amsterdam 2013a, available at: http://www.ois.amsterdam.nl/media/Amsterdam\% 20in\% 20cijfers\% 202013/HTML/ $\# / 62 /$. [20.03.2015].

Gemeente Amsterdam: Amsterdamse Armoedemonitor 2012. Amsterdam 2013b, available at: http://www.ois.amsterdam.nl/pdf/2013_armoedemonitor_2012.pdf [01.05.2015].

Graham, Pamela: International Migration and Transnational Politics: Recent Developments in the Caribbean and Mexican Cases, paper presented at the Meeting of the Latin American Studies Association in Guadalajara, Mexico, 17.-18. 04.1997, available at: http://maxweber.hunter.cuny.edu/pub/eres/SOC217_PIMENTEL/graham.pdf [26.09.2016].

Hasalová, Jana: "Transnational development agency of migrants: problematic aspects of research on remittances", in: Beyond Globalisation: Exploring the Limits of Globalisation in the Regional Context. Ostrava, Czech Republic 2010, pp. 147-153, available at: http://conference.osu.eu/globalization/publ/18-hasalova.pdf [11.11.2014].

Kyei, Justice. Richard. K. O. / Smoczynski, Rafal: "Building bridges or bonds: the case of Ghanaian second generation migrants in Ghanaian churches in Amsterdam", in: Romanian Journal Antropological Research and Studies (6) 2016, pp. 13-24, available at: http://www.journalstudiesanthropology.ro/en/no-6-2016/r46/ [14.10.2016].

Levitt, Peggy / Glick-Schiller, Nina: "Conceptualizing simultaneity: A transnational social field perspective on society”, in: International Migration Review (38/3) 2004, pp. 1002-1039, available at: http://onlinelibrary.wiley.com/doi/10.1111/j.1747-7379. 2004.tb00227.x/epdf [26.09.2016].

Lindley, Anna: "The North-South Divide in Everyday Life: Londoners Sending Money 'Home'", in: Bildhaan: An International Journal of Somali Studies (9/1) 2011, pp. 3962, available at: https://www.ciaonet.org/attachments/18300/uploads [26.09.2016]. 
Martiniello, Marco: Political participation, mobilisation and representation of immigrants and their offspring in Europe (= Willy Brandt Series of Working Papers International Migration and Ethnic Relations 1/5) 2005, available at: http://dspace.mah. se/bitstream/handle/2043/1495/WB_1-05.pdf;jsessionid=5457CDAF2B5F606FE39A 0C77D5492B14? sequence=1 [26.09.2016].

Mazzucato, Valentina: Ghanaian migrants' double engagement: a transnational view of development and integration policies (= Global Migration Perspectives 48), Geneva: Global Commission on International Migration 2005, available at: https://www.unitar. org/ny/sites/unitar.org.ny/files/GCIM_Ghanian\%20migrants.pdf [26.09.2016].

Mensah, Joseph: “Doing Religion' Overseas: The Characteristics and Functions of Ghanaian Immigrant Churches in Toronto, Canada", in: Societies Without Borders (4) 2009, pp. 21-44, available at: http://scholarlycommons.law.case.edu/cgi/viewcontent. cgi ?article $=1122 \&$ context $=$ swb [26.09.2016].

Miller, Alan S. / Hoffmann, John P.: "Risk and Religion. An Explanation of Gender Differences in Religiosity", in: Journal for the Scientific Study of Religion (34) 1995, pp. 63-75, available at: https://www.jstor.org/stable/1386523?seq=1\#page_scan_tab_ contents [26.09.2016].

Mügge, Liza: Beyond Dutch Borders: Transnational Politics among Colonial Migrants, Guest Workers and the Second Generation. Amsterdam 2010, available at: https:// www.imiscoe.org/docman-books/265-muegge-2011/file [26.09.2016].

Nijenhuis, Gery / Zoomer, Annelies / Meerts, Annelien: Transnational activities of immigrants in the Netherlands: Do Ghanaian, Moroccan, And Surinamese diaspora organizations enhance development, paper presented at $2^{\text {nd }}$ meeting of the Transnational Organizations Network in Princeton, 11.-12.5.2012, available at: https://www. princeton.edu/cmd/working-papers/2012TransnationalMeeting/2012-Netherlands. pdfPrinceton [21.12.2015].

Setrana, Boatemaa M. / Kyei, Justice Richard K. O.: "L'engagement politique de la diaspora ghanéenne aux Pays-Bas (Transnational Paradigm within Immigrant Political Integration Discourse: The Case of Ghanaians in the Netherlands)", in: Afrique Contemporaine (256/4) 2015, pp. 91-101, available at: http://www.cairn.info/resume. php?ID_ARTICLE=AFCO_256_0091 [05.07.2016].

Sinning, Mathias: Home-ownership and economic performance of immigrants in Germany (= RWI Discussion Papers, No.45), Essen 2006, available at: http://creammigration.org/files/paper_sinning.pdf [26.09.2016].

Smart, Alan / Smart, Josephine: "Urbanization and the global perspective", in: Annual Review of anthropology (32) 2003, pp. 263-285, available at: http://www.annualre views.org/doi/full/10.1146/annurev.anthro.32.061002.093445 [26.09.2016].

Statistics Netherlands: "Population; sex, origin and generation, 1 January", in: The Hague / Heerlen (eds.): Statistics Netherlands 2015, available at http://statline.cbs.nl/ StatWeb/publication/?DM $=$ SLEN\&PA $=37325 E N G \& D 1=0 \& D 2=a \& D 3=0 \& D 4=$ $0 \& \mathrm{D} 5=0,85 \& \mathrm{D} 6=11-17 \& \mathrm{LA}=\mathrm{EN} \& \mathrm{HDR}=\mathrm{G} 2, \mathrm{G} 3, \mathrm{G} 4, \mathrm{~T} \& \mathrm{STB}=\mathrm{G} 1, \mathrm{G} 5 \& \mathrm{VW}=\mathrm{T}$ [26.09.2016].

Tonah, Steve: "Ghanaians Abroad and Their Ties Home: Cultural and Religious Dimensions of Transnational Migration", in: Working Papers, Center for Interdisciplinary Research. Bielefeld, Germany 2007, available at: https://www.uni-bielefeld.de/ tdrc/ag_comcad/downloads/workingpaper_25_Tonah.pdf [26.09.2016]. 
Vernooij, Joop: Pentecostalism and Migration - The Dutch Case, paper for the IAMS Assembly in Malaysia 2004, available at: http://missionstudies.org/archive/confer ence/1papers/fp/Joop_Vernooij_pentecostalism_Full_Paper.pdf [26.09.2016]. 